\title{
Gemeinsame Leidenschaft
}

Liebe Leserin, lieber Leser,

innerhalb eines Jahres einen fahrtauglichen Rennwagen selbst zu konstruieren, das ist im Alleingang kaum möglich. Aber gemeinsam ist es machbar. Diese Erfahrung haben die ehemaligen Formula-Student-Teilnehmer gemacht, die im Jahr 2005 die Grundidee entwickelt haben, einen solchen Wettbewerb auch in Deutschland zu veranstalten. Dieses Jahr fand die Formula Student Germany nun zum zehnten Mal am Hockenheimring statt. Und seither teilen diese Erfahrung noch viel mehr Menschen.

Denn seit die Initiatoren die Veranstaltung 2006 erstmals am Hockenheimring durchgeführt haben, ist die Begeisterung von Hunderten von ehrenamtlichen Helfern, von Teilnehmern, Veranstaltern und Sponsoren ungebrochen. Mehr noch: Von Jahr zu Jahr wird die Veranstaltung ein bisschen weiter optimiert. Mal eher dezent und mal mit einem Paukenschlag wie im Jahr 2010, in dem erstmals auch rein elektrisch angetriebene Fahrzeuge an den Start gingen.

Das Erfolgsprinzip davon, zunehmend professioneller zu werden und dabei gleichzeitig mit Spaß an der Sache zu bleiben, erklärt Tim Hannig im Interview in dieser Ausgabe. Die Basis für den Erfolg ist das Teilen. Die Macher der Formula Student Germany teilen ihre Erfahrungen mit anderen FormulaStudent-Veranstaltern auf der ganzen Welt. Erfahrene Ingenieure geben ihr
Wissen an Jungingenieure weiter, und Teams teilen ihre Erfahrungen mit anderen Teams. Und alle teilen die gemeinsame Begeisterung für die geschaffene Leistung: den konkurrenzfähigen Rennwagen.

Die ATZ/MTZ-Redaktion hat die Veranstaltung von Anfang an mit einem Sonderheft begleitet. So faszinieren uns auch bei unserer zehnten Ausgabe immer noch die Leistungen und die Leidenschaft der Teilnehmer. Deshalb freuen wir uns, Ihnen auch im Jubiläumsjahr einige spannende technische Entwicklungen der Teams präsentieren zu können.

Ich wünsche Ihnen viel Spaß bei der Lektüre!

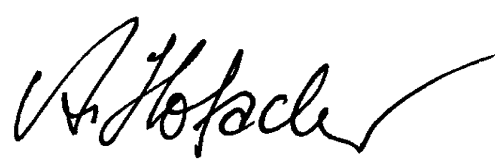

Angelina Hofacker, Redaktion ATZ

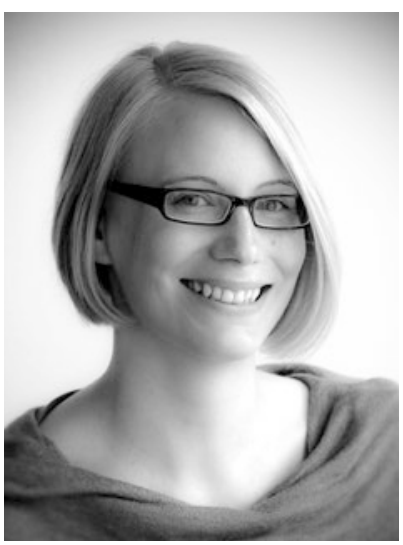

Shared Passion

Dear Reader,

Building a drivable racing car oneself within the space of a year - that can hardly be done single-handedly. But together with others, it is indeed possible. This was the experience gained by former Formula Student competitors who, back in 2005, developed the basic idea of organising such a competition in Germany too. This year, Formula Student Germany took place for the tenth time at the Hockenheimring. And since the competition began, this experience has been shared by many more people.

Ever since the initiators staged the event for the first time in 2006, the enthusiasm of hundreds of voluntary helpers, competitors, organisers and sponsors has never waned. And what is more: the event is optimised a little further year by year. Sometimes with a small step and sometimes with a giant leap forward, as in 2010 when the first all-electric cars lined up on the grid in Hockenheim.

The special ingredient - becoming increasingly professional while at the same time having fun - is described by Tim Hannig in our interview in this issue. The basis for success is sharing. The organisers of Formula Student Germany share their experiences with their counterparts throughout the world. Experienced engineers pass their knowledge on to young novices, and teams share their experience with other teams. And all share a common enthusiasm for their proud achievement: a competitive racing car.

The ATZ/MTZ editorial team has accompanied the event right from the start by publishing a special issue. Our tenth issue is once again full of enthusiasm for the achievements and passion of all those taking part. For that reason, we are very pleased to present some of the outstanding technical developments by the teams in this anniversary year.

I hope you enjoy this special issue. 